Volume and Issues Obtainable at Center for Sustainability Research and Consultancy

Journal of Accounting and Finance in Emerging Economies

ISSN: 2519-0318ISSN (E) 2518-8488

Volume 4: Issue 2 December 2018

Journal homepage: publishing.globalcsrc.org/jafee

\title{
Sukuk Issuance in Malaysia: Lessons for Pakistan
}

\author{
${ }^{1}$ Sumaira Ghafoor, ${ }^{2}$ Irum Saba, ${ }^{3}$ Rehana Kouser \\ ${ }^{1}$ Data Analyst/Visiting Lecturer Karachi, Pakistan. \\ ${ }^{2}$ Professor, Department of Commerce, Bahauddin Zakariya University, Multan, Pakistan. \\ reahanakousar@bzu.edu.pk \\ ${ }^{3}$ Assistant Professor, Program Director MS Islamic Banking \& Finance \\ Institute of Business Administration, Karachi, Pakistan. isaba@iba.edu.pk
}

ARTICLE DETAILS

\section{History}

Revised format: Nov2018

Available Online: Dec 2018

\section{Keywords}

Sukuk Market, Malaysia, Murabaha, Ijarah, Mudarabah

JEL Classification:

L10

\section{ABSTRACT}

Pakistan need to enhance the liquidity management framework for its growing Islamic finance industry. Sukuk is a best Shariah-compliant debt instrument for short term liquidity needs since Sukuk is highly tradable instrument with low level of market risk. In view of that, there is an increasing trend in the global issuances of corporate and sovereign Sukuk. Therefore, this case study aims to explore the issuance of Sukuk in Malaysia as an example. Malaysia is dominating the Sukuk Market and has been issuing Sukuk since 1990. The underlying structure of the proposed Sukuk model for Pakistan is Istisna that is an Islamic project bond. Pakistan has the potential to replicate the Sukuk model of Malaysia. However, it is required to have an active secondary trading market in order to develop an effective and dynamic Sukuk market.

(C) 2018 The authors, under a Creative Commons AttributionNonCommercial 4.0

Corresponding author's email address: reahanakousar@bzu.edu.pk

Recommended citation: ${ }^{1}$ Ghafoor, S., ${ }^{2}$ Saba, I. ${ }^{3}$ Kouser, R., (2018). Equity Liquidity and Firm Investment: Evidence from Pakistan. Journal of Accounting and Finance in Emerging Economies, 4(2)159-176

DOI: $10.26710 /$ jafee.v4i2.525

\section{Introduction}

Islamic law forbids the exchanging of short term debt tool at other than intrinsic value, or from drawing upon the traditional interbank money markets since these exchanges comprise of interest (Riba- and uncertainty (Gharar). This implies that Islamic financial institutions have a tendency to have profoundly liquid balance sheets with restricted opportunities for the placement of funds. Therefore, Sukuk as an asset-backed trust certificate is a great opportunity for short and medium term placement of such finances in a Shariah compliant manner.

Sukuk can be defined as "Sukuk, in Islamic finance parlance, refer to the ownership of claims against certain assets or a pool of assets. Technically, Sukuk are certificates of equal value that represent units (undivided shares) in ownership of tangible assets, usufructs (manfa'ah), and services." Generally a special purpose vehicle (SPV or issuer) issues Sukuk, which are trust certificates. The proceeds of Sukuk are lent to a corporation, financial institution, insurance company, the government to raise funds in a Shariah compliant manner. The modes underlying Sukuk can be Murabaha, Wakala, etc., reflecting either 
investment or financing contracts. (S \& P Global Ratings, 2017). Sukuk, the Shariah-compliant debt instrument, is one of the major component of the Islamic monetary and capital market which is connected in project financing and other main activities. Its position as a solid and dynamic instrument in the monetary development and budgetary security has been for quite some time recognized. The presence of Sukuk gives another change in outlook to get financing to help economic activity. (Saripudin, Mohamad, Razif, Abdullah, \& Abdul Rahman, 2012)

Sukuk gives the ownership rights in specific assets to some extent as opposed to debt. Sukuk is issued in a manner corresponding to the principles of Murabaha, Mudarabah, Musharakah, Ijarah, Istisna, Wakalah, and other modes of finance. Structure of Sukuk based on Islamic contracts is shown in the following diagram (Figure 1):

Figure 1: Sukuk Structures based on Islamic Contracts

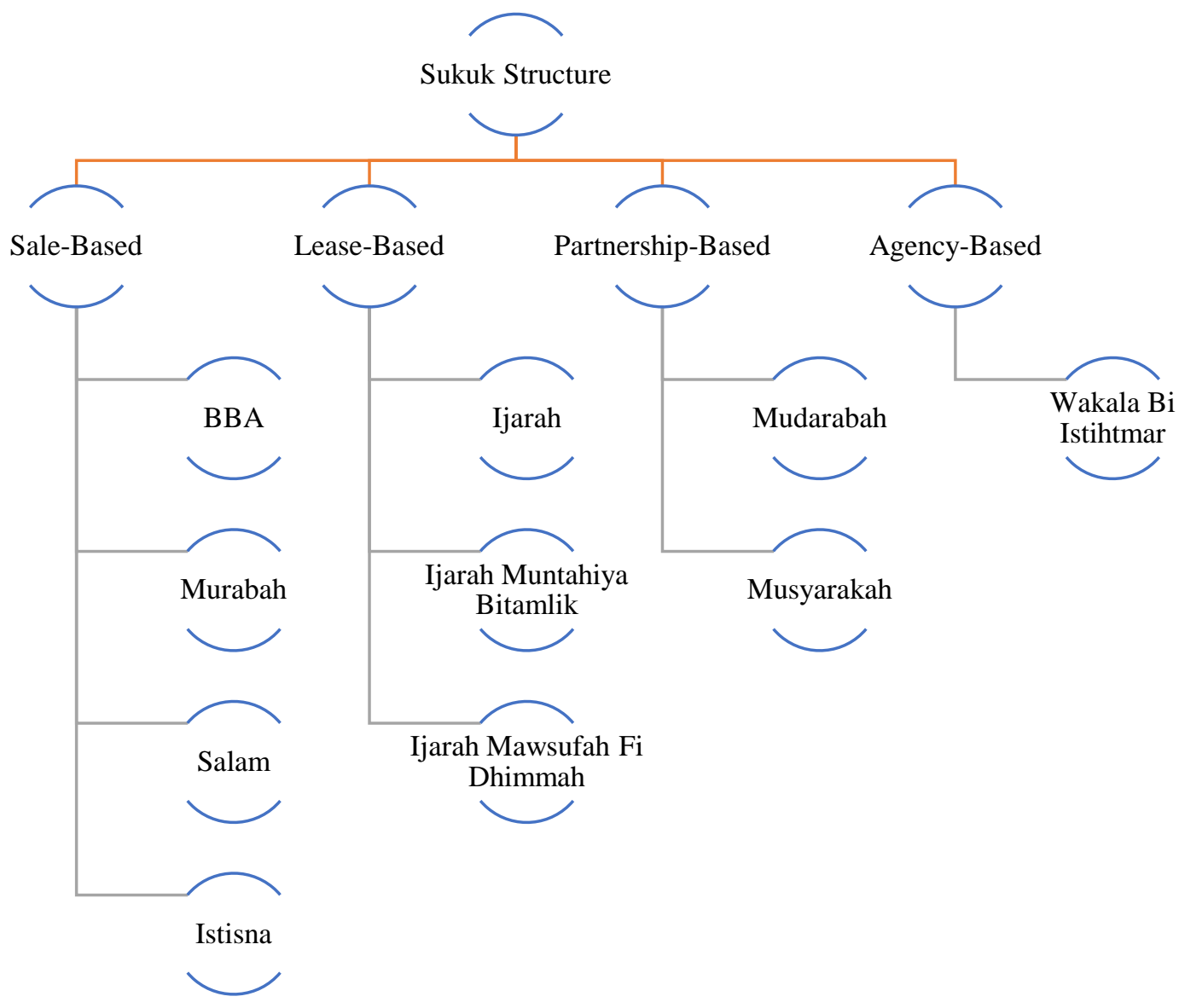

As illustrated in Figure 1, there are four major categories of Sukuk; (1) Sale-based (2) Lease-based (3) Partnership-based (4) Agency-based. Various countries are using Sukuk for managing capital needs including Bahrain, Brunei, Egypt, Gambia, Indonesia, Iran, Malaysia, Kazakhstan, Kuwait, Pakistan, Qatar, Saudi Arabia, Singapore, Somalia, Turkey, United Arab Emirates, United Kingdom, and Hong Kong.

Figure 2: Size of Sukuk 


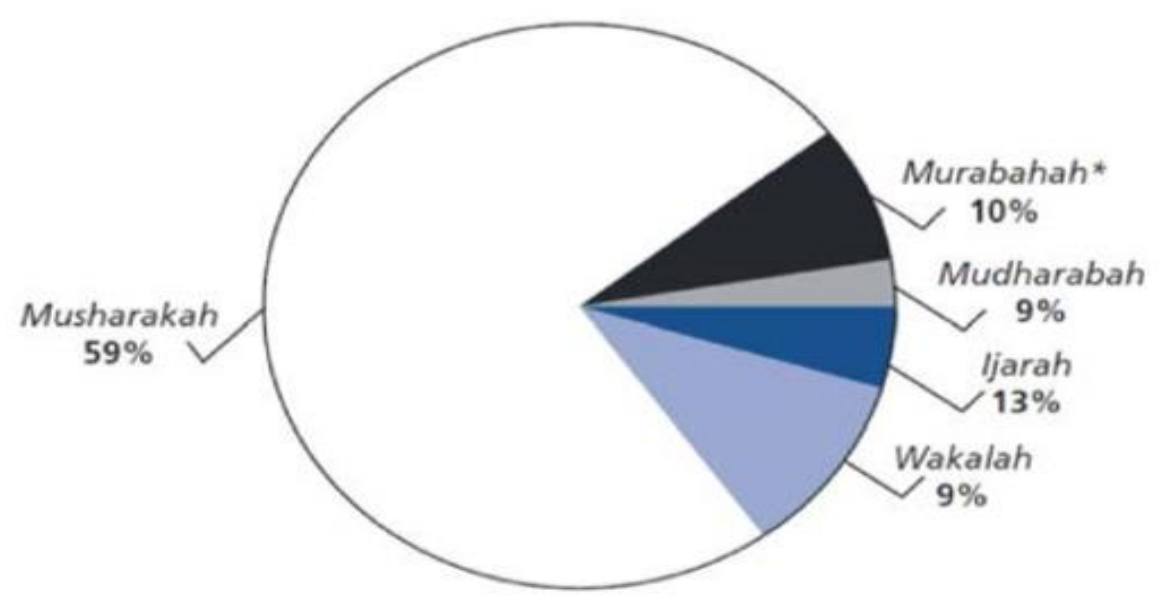

The assets and deposits of Islamic banking industry in Pakistan are Rs. 2,083 billion and Rs. 1,729 billion with the market share 11.9 percent and 13.7 percent respectively as stated by the Islamic Banking Bulletin issued by State Bank of Pakistan in September 2017. The current Islamic banking industry comprises of 21 Islamic banking institutions including 5 full-fledged Islamic banks and 16 conventional banks with Islamic banking branches with a network of more than 2,368 branches. The ratio of liquid assets to total assets is 28.8 percent while the liquid assets to total deposit ratio is equal to 34.7 percent.

Liquidity risk management is a tool to make use of surplus funds. And a thorough liquidity risk management could raise funds to fulfill the requests of investors and borrowers whenever they demand with a satisfactory price. Liquidity risk management is one of the major challenge that Islamic financial institutions have in Pakistan due to the nonexistence of an Islamic inter-bank market, lack of alternatives compliant with Islamic principles, deficiency of short term and long term Islamic Sukuk, and absence of Islamic discount window at State bank of Pakistan for Islamic Financial institutions. Placement of additional funds and meeting the short falls \& short term liquidity needs are the two sides of liquidity management issue.

This paper is an attempt to solve liquidity management issues from the experience of Malaysia. Liquidity management issue can be solved through the development of Sukuk market in Pakistan. Pakistan, as a developing country, has restricted access to capital to invest in main sustainable infrastructure because of the dependence on local bank loans with inappropriate terms and conditions. Therefore, it is required to enhance the liquidity management framework for the development of Islamic finance industry in Pakistan.

\section{Background}

Islamic financial services industry developed in the mid-1970, when new Islamic financial institutions began proposing Shariah-compliant financial products because of developing societal request. Despite the fact that its standards have existed since the beginning of Islam, existing Islamic finance is as yet not fully formed, its total assets of US \$ 2 trillion out of 2017 are very small in contrast to the global finance market. Though it is advancing quickly, and it possibly serves both a rising 1.7 billion Muslim population worldwide and progressively intrigued non-Muslim investors.

The Islamic finance market depends on the preclusion of interest based transactions, which violates the Islamic principles, alongside other rejected or haram transactions, for example, conventional insurance, gambling, and the offer of weapons, alcohol, pork, and erotic entertainment. The most widely recognized transactions incorporate Murabaha, Ijarah, and Mudarabah and other Islamic modes of finance, whereas Sukuk considered as the most well-known instrument of Islamic capital markets based on these transactions. Governments and regulatory authorities from Pakistan and Malaysia are eagerly promoting Islamic finance products while guaranteeing appropriate oversight of the Islamic financial market.

There are three main sectors of Islamic financial services industry: Islamic Banking, Islamic Capital Market, and Takaful. Sectoral composition of the global Islamic financial services industry is given in the following figure (see Figure 3). 
Figure 3: composition of three different sectors of Islamic finance services industry.

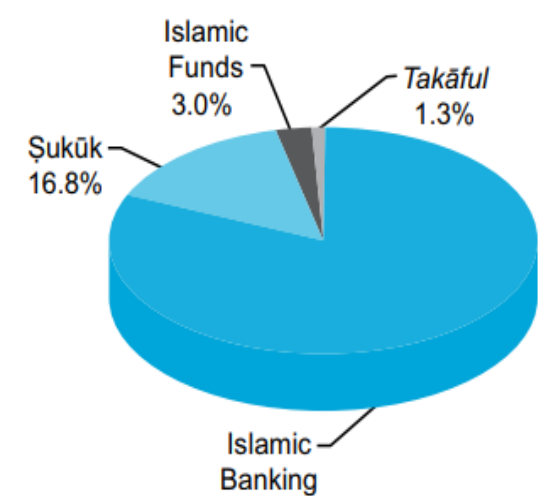

$78.9 \%$
The

Islamic biggest share (i.e. 78.9 percent) in financial services industry is of Islamic banking. The share of Islamic capital market and Takaful are 19.8\% and 1.3 percent respectively. Islamic banking industry is growing around the world. And the value of global Islamic banking assets has increased. Key Islamic banking markets are Egypt, Malaysia, Indonesia, Iran, Saudi Arabia, Pakistan, Bahrain, UAE, Sudan, Kuwait, Bangladesh, Brunei, Turkey, Qatar, Oman, Jordan and others. Global Islamic Banking Assets shares in several countries in US Dollars terms are presented in the next figure (Figure 4). Iran, Saudi Arabia, and Malaysia have the largest Islamic banking assets with the share of 33.0 percent, 20.6 percent, and 9.3 percent respectively.

Figure 4: Shares of Global Islamic Banking Assets.

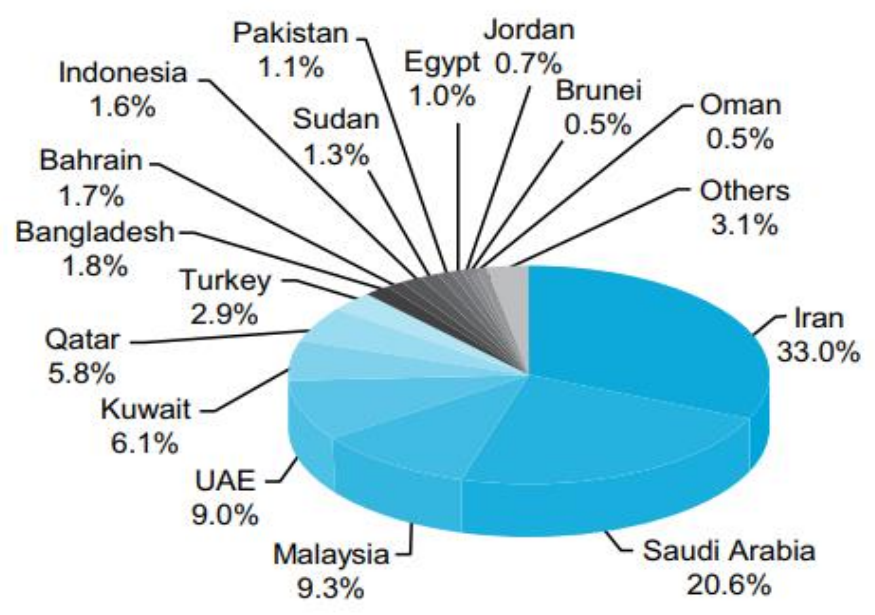

The breakdown of average annual growth rate of Islamic banking in terms of assets, financing, and deposits is provided in Figure 5. Figure 5 consists of the average annual growth rates of Turkey, Pakistan, Bangladesh, Saudi Arabia, Indonesia, Oman, Kuwait, Iran, Qatar, Jordan, Kuwait, Malaysia and Nigeria between second quarter of 2015 and second quarter of 2016. Deposits of Malaysian Islamic banks grew with the rate of 8.2 percent, while the deposits of Islamic banks and windows in Pakistan grew with the rate of 14.1 percent. The financing growth in Pakistan was 31.8 percent compared to 12 percent in Malaysia.

Figure 5: Growth rate of Islamic banking in terms of assets, financing, and deposits. 


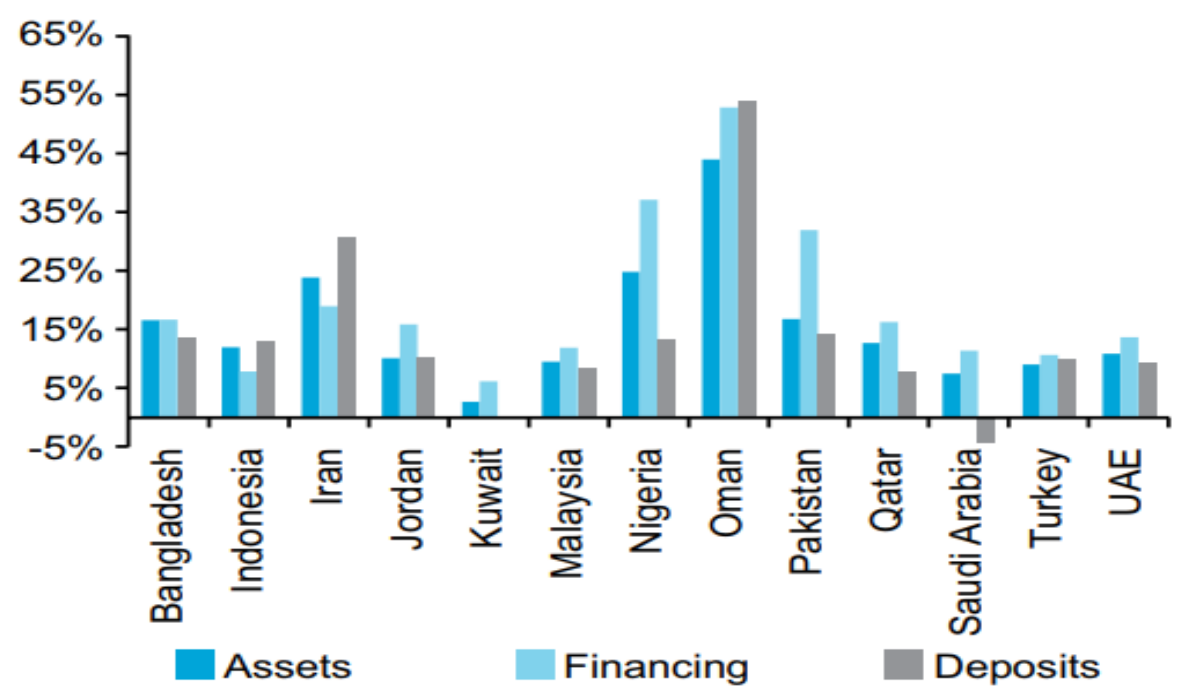

In general, financial institutions without having sufficient liquidity, confront different types of risks which might have prompt influence on their overall financial stability.

Mobin \& Ahmad, 2014 analyze that how Malaysian Islamic finance industry is managing the liquidity risk. For this analysis, the sample of 15 Malaysian Islamic banks is being taken. It is found that size, return on Equity, and specialization are some of the determinants of liquidity risk management. Results indicate that Islamic banks which are bigger in size and more specialized in terms of lending activity more likely to manage liquidity risk effectively.

Similarly, Mohamad, Mohamad, \& Samsudin, 2013 assess the way Islamic banking sector of Malaysia is managing the liquidity risk while considering the macroeconomic control variables. This study is based on panel data estimations with the sample of 17 Islamic banks of Malaysia. The findings provide evidence that macroeconomic control variables affect the behavior of Islamic banking industry in managing liquidity. It is suggested that Islamic financial institutions should determine the reason and objectives of the credit application to be consistent with the institution's financial policy so as not to cause any issue in the future. This is vital on the grounds that without a right and solid reason, issued financing would be a danger of reimbursement ambiguities which will influence the liquidity of the Islamic financial institution.

Sukuk is considered as the best instrument to absorb the surplus liquidity of Islamic Financial Institutions because it is highly tradable instrument with low level of market risk. Therefore, this market is growing with the growing Shariah-compliant investments. The global aggregate Sukuk historical trend is presented in the following figure (Figure 6):

Figure 6: Historical Trend 


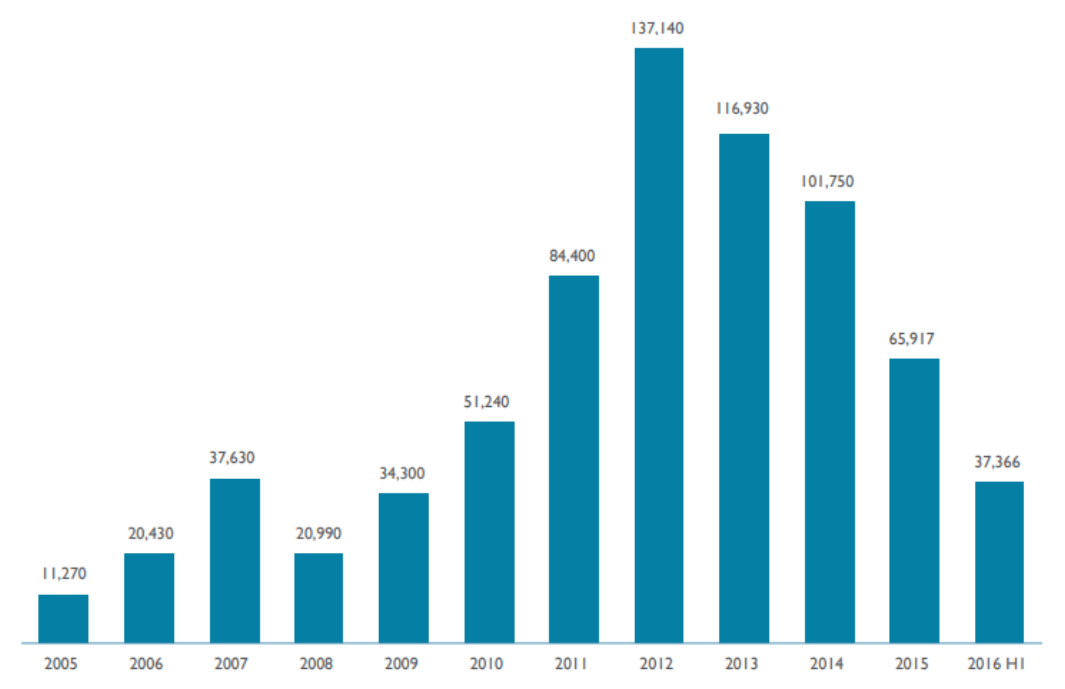

Inspite of the immense development in the Sukuk market in the past 13 years, there is still a shortage situation in the Sukuk market where demand is greater than the supply.

Figure 7: Global Sukuk Issuances - Sovereign and Corporate.

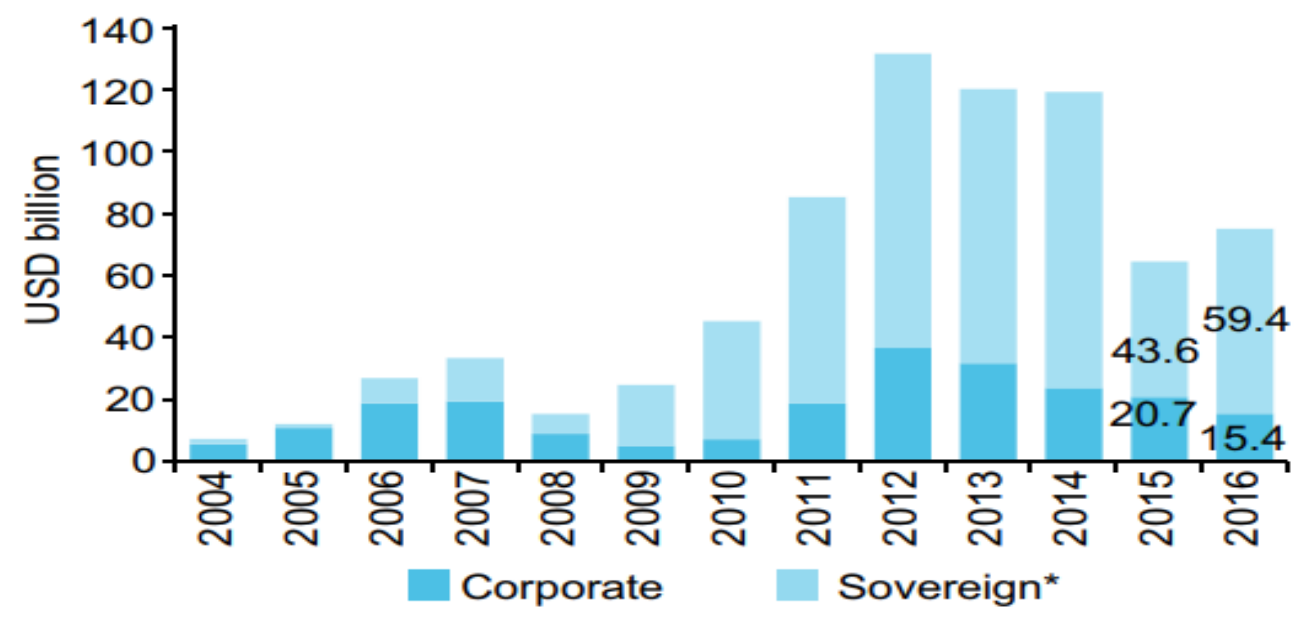

* Contains all Government-Related Entities (GREs), Multilateral Development Banks (MDBs) and International Organizations (IOs). Here, "GREs" denotes to Sukuk holders with more than two thirds $(66.67 \%)$ shares in government ownership e.g. ministries, authorities, sovereign wealth funds etc.

Several countries are issuing sovereign Sukuk including, Malaysia, Indonesia, UAE, Saudi Arabia, Turkey, Pakistan, Qatar, Bahrain, Oman, Brunei, Senegal, Cote d'lvoire, Togo, Kuwait, Jordan, and Gambia. However, Malaysia is a dominant country in issuing sovereign Sukuk with the share of 50.8 percent. Whereas, the total sovereign Sukuk issuance of pakistan is only 4.8 percent. As far as corporate Sukuk issuance is concerned, Malaysia continue to dominate the market. The corporate issuers of Malaysia are leading with the share of 50.2 percent. One of the reason is that corporate issuers of Malaysia are using different underlying structures based on Islamic principles in the issuance of corporate Sukuk. Besides, UAE and Saudi Arabia ranked second and third in corporate Sukuk issuances with 18.3 percent and 11.6 percent corresponding shares. Moreover, Pakistan has no share in corporate Sukuk issuance market in 2015-2016.

Figure 8: Sovereign Sukuk Issuances. 


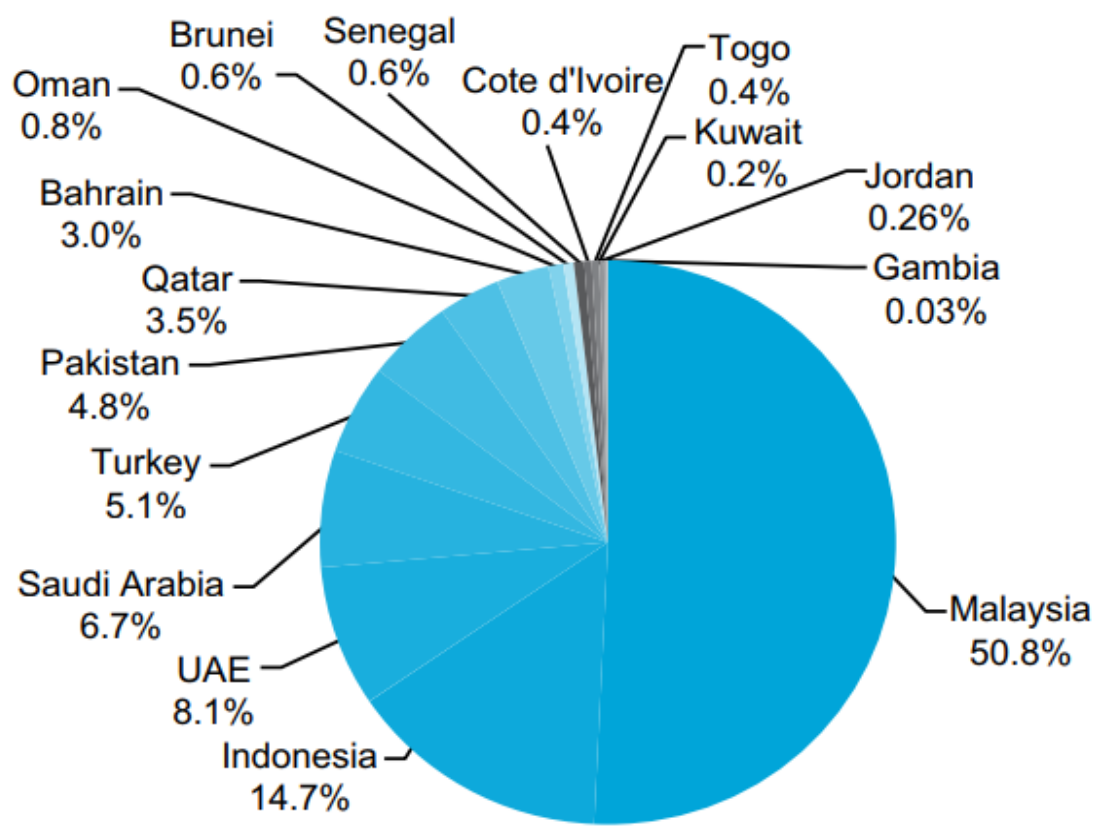

Figure 9: Corporate Sukuk Issuances

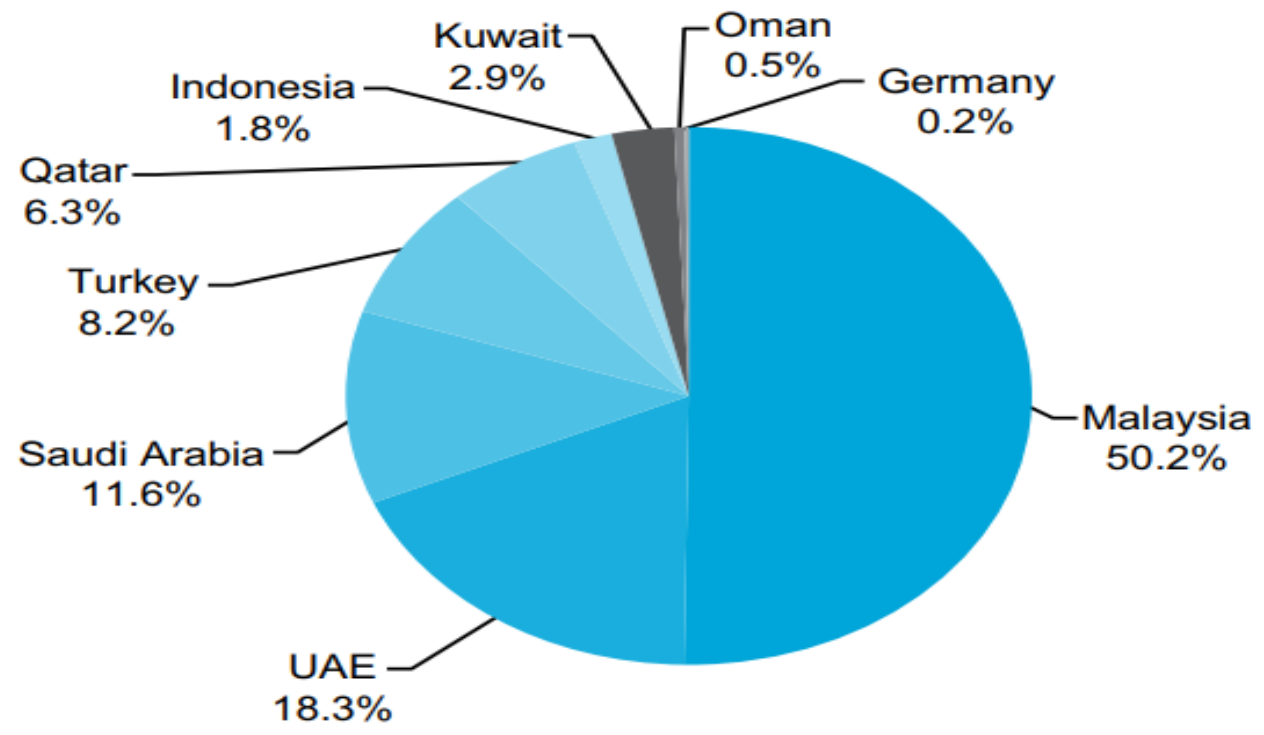

Figure 10: Sukuk Issuances by Sector 

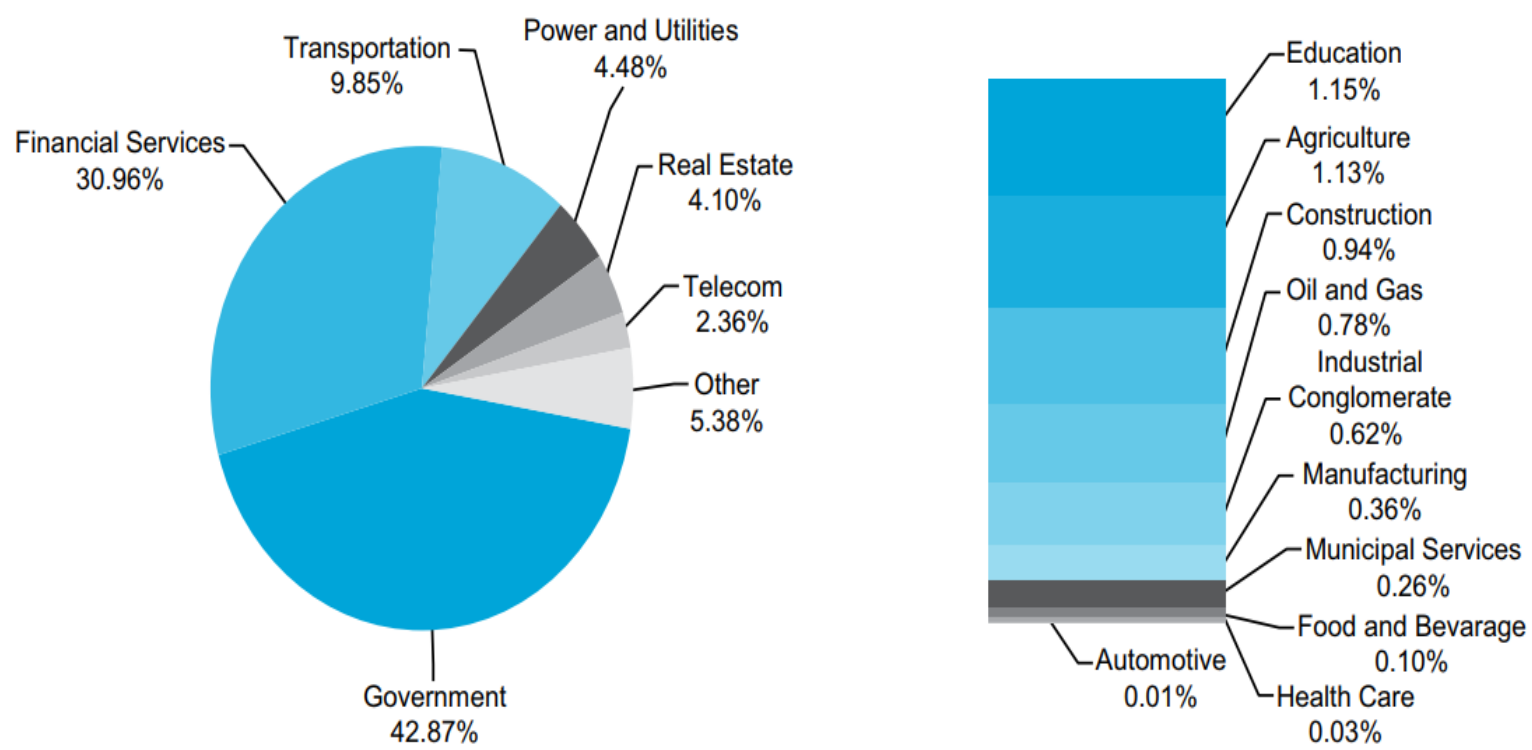

Breaking down Sukuk issuances by part, the government has the largest share (i.e. 42.87 percent). In addition financial services sector keeps on dominating the market with 30.96 Percent (Figure 10: Sukuk Issuances by Sector Figure 10). Altogether, the power and utilities, transportation and telecommunication sectors represented as $16.7 \%$ (power and utilities with 4.48 percent shares, transportation with 9.85 percent shares and telecommunication sector with 2.36 percent shares) of aggregate Sukuk issuances. The Real Estate sector representing 4.10 percent of the market. Apart from these sectors, sectors like education, agriculture, construction, oil and gas, industrial conglomerate, manufacturing, municipal services, food and beverage, health care, and Automotive contributed in the Sukuk market with the share of 1.15 percent, 1.13 percent, 0.94 percent, 0.78 percent, 0.62 percent, 0.36 percent, 0.26 percent, 0.10 percent, 0.03 percent, and 0.01 percent respectively.

The fundamental Shariah rulings on the issuance of Sukuk in the Islamic monetary and capital market of Malaysia has been elaborated by Mohamad \& Yusoff, 2008. Awadzi, 2015 discussed legal frameworks for sovereign Sukuk issuance.

Saripudin, Mohamad, Razif, Abdullah, \& Abdul Rahman, 2012 give the hypothetical idea of Sukuk Musharakah and examine the compliancy of Sukuk Musharakah issued by Kuala Lumpur Sentral Sdn. Bhd. (KLSSB) as per Islamic principles by studying the problems related with it.

Yean, 2009 specifically talks about the problems of its initial stage of development. Legal restrictions under the current legal system of specific rule, the problem of enforceability of agreements, extraterritorial issues, and the absence of very much organized and well-regulated secondary market for Sukuk are some of main issues of Sukuk industry identified in this paper. In addition, it investigates the perceptions and resolutions of the Shariah board of Accounting and Auditing Organization for Islamic Financial Institutions (AAOIFI). It is suggested that it is necessary to look over the Sukuk structure which involves the joint efforts of the governments, market suppliers, regulators, investors, legal advisor, and Islamic law scholars. Moreover, integrated documentation frameworks need to be developed for the growth and development of Islamic finance around the world.

Ahmad \& Radzi, 2011 examine the sustainability of Sukuk issuance and traditional bond in Malaysia at the time of financial crises by analyzing the following three factors: Gross Domestic Product (GDP), foreign exchange, and market liquidity. This study is based on the 20 years' data (i.e. from 1990 to 2009) and Ordinary Least Square (OLS) regression. It is found that Sukuk is less influenced from the financial crises as compared with conventional bond due to different underlying structure. Gross domestic product, foreign exchange, and worldwide liquidity are considered for the issuance of Sukuk. On the other hand, 
conventional bond issuers place a premium on foreign exchange only.

Abdul Majid, 2003 discusses the main aspects of liquidity management in Islamic banks and challenges and opportunities of liquidity management instruments. Six main causes of liquidity issues are summarized in this paper including; small number of members, the sluggish growth of Islamic financial instruments, the absence of Shariah-compliant interbank market, no liquid Islamic secondary market, the absence of lender of last resort facilities, and different interpretation of Islamic principles.

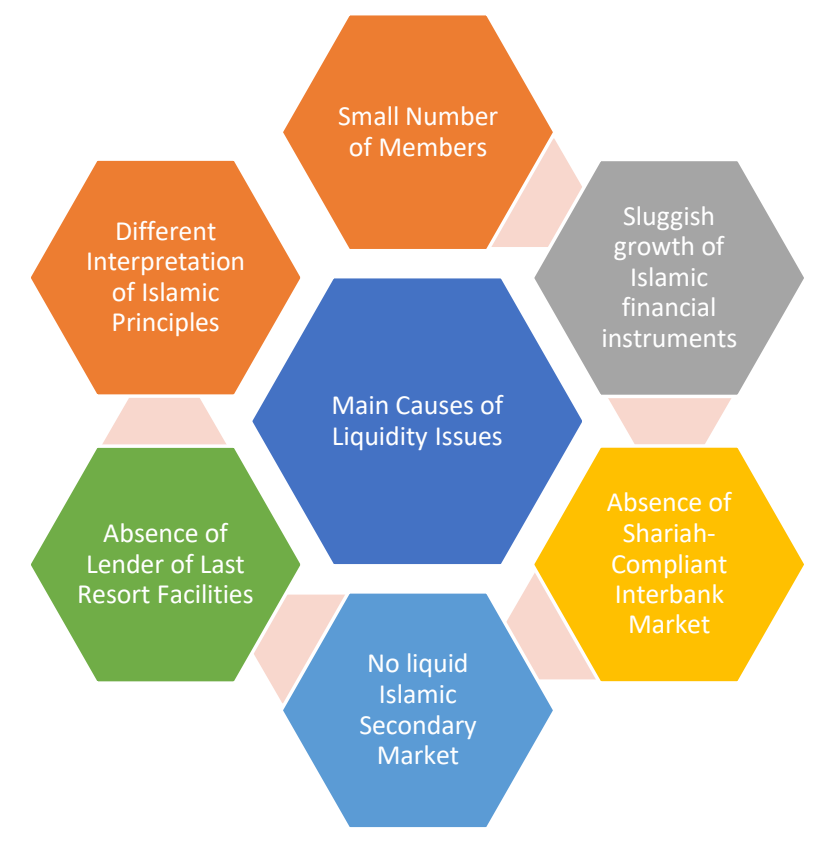

\section{Examples of Malaysia}

The main sectors of Islamic financial services industry of Malaysia are: Islamic banking, takaful, Islamic capital market, asset management and wealth, and financial planning. In 1983, the first Islamic bank known as Bank Islam Malaysia Berhad was set up which deals with Shariah-compliant financial activities. The Bank Islam Malaysia Berhad manages its liquidity through the non-interest bearing Government Investment Certificates (GIC) which was based on the principle of Qard ul Hasan. In 1993, 17 conventional banks started their Islamic banking windows under Interest-Free Banking Scheme. As a result, Islamic money market established in Malaysia. In 2002, Bank Negara Malaysia properly issued licenses to the subsidiaries of conventional banks operating Islamic Banking through windows (Alhabshi, 2013). By now, 5 full-fledged Islamic banks, 11 conventional banks who have established Islamic subsidiaries are operating in Malaysia. In terms of growth, the Islamic financial institutions in Malaysia is expanding with total assets US \$ 414 billion.

Malaysia has also developed its Takaful Industry. Syarikat Takaful Malaysia Berhad was the first Takaful Company set up in 1985 in Malaysia to provide Shariah-compliant insurance. In 1994, the second Takaful company Malaysian National Insurance (MNI) Takaful was established. Currently, Malaysia's Takaful Industry consists of 11 Takaful Companies including domestic and international Takaful Operators.

Malaysia, a global Islamic finance has issued the highest number of Sukuk. The first Sukuk was issued in 1990 through Shell MDS (Malaysia) and the first corporate Sukuk global Guthrie in 2003. The Malaysian Sukuk market experienced its development boom from 2001-2008 during which the average growth rate was $21 \%$. By this time, the amount corporate Sukuk issued exceeded the value of outstanding corporate bonds. Malaysia as the leader of Islamic finance industry occupies the major share of the Sukuk industry since the inception, though the share has been expanding but still the major player remains Malaysia. A 
new trend in Sukuk is the issuance of "green Sukuk" and "social impact Sukuk" to fulfill the needs of Shariah compliant, environmentally friendly and socially responsible businesses. One important reason for this innovation in Sukuk issuances was to actively compete with the global Sukuk market. Securities Commission of Malaysia (SC) launched the Sustainable and Responsible Investment (SRI) Sukuk Framework in 2014 to facilitate the financing of sustainable and responsible investment initiatives.

The market share of Malaysian Sukuk market is 28.8 percent with RM 138.7 billion Sukuk issuance. The overall statistics of Malaysian Sukuk Market and corporate Sukuk statistics are presented in Figure 11 and Figure 12 respectively.

Figure 11: Sukuk Market overall Statistics

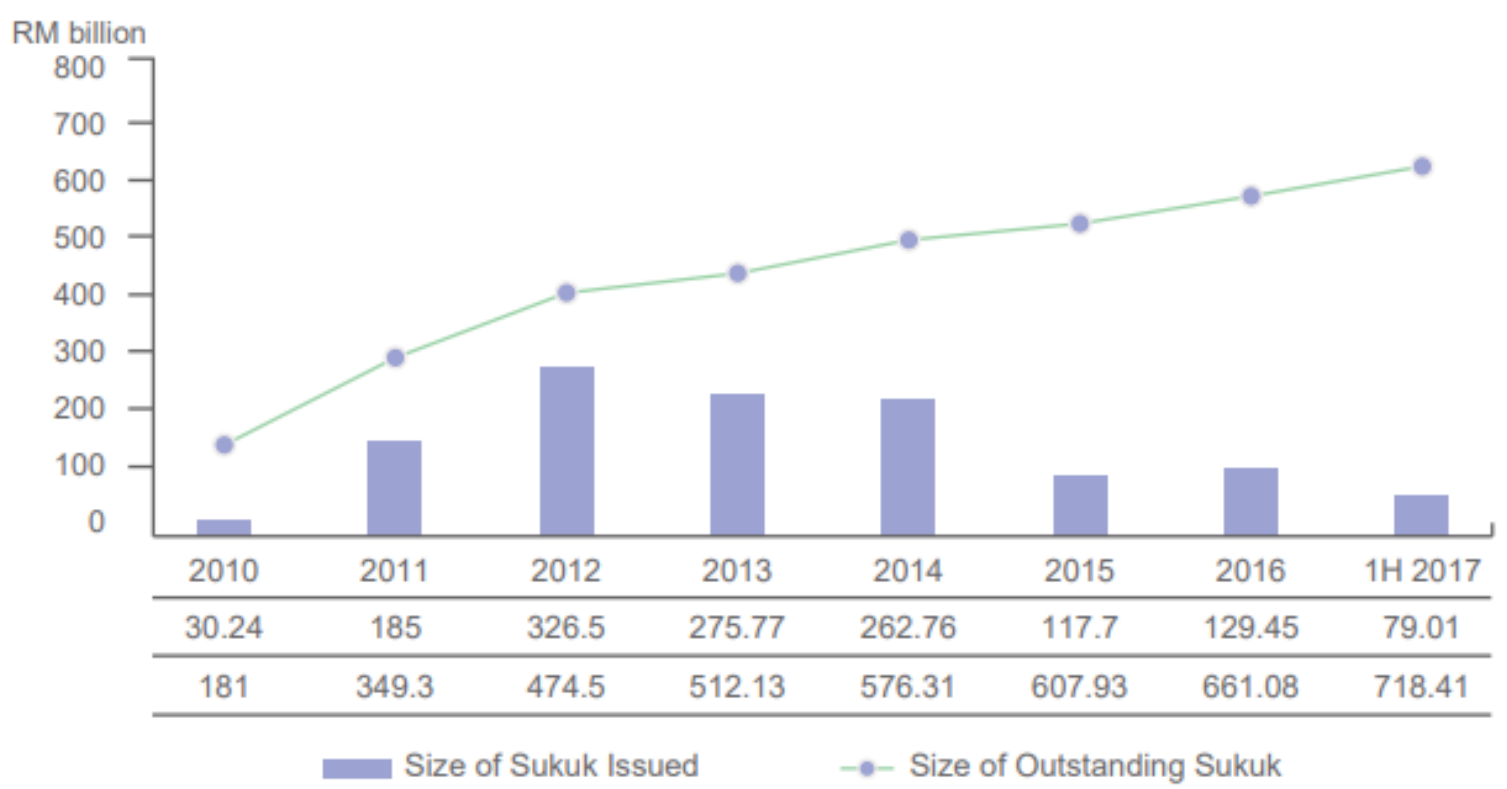

Figure 12: Corporate Sukuk Statistics

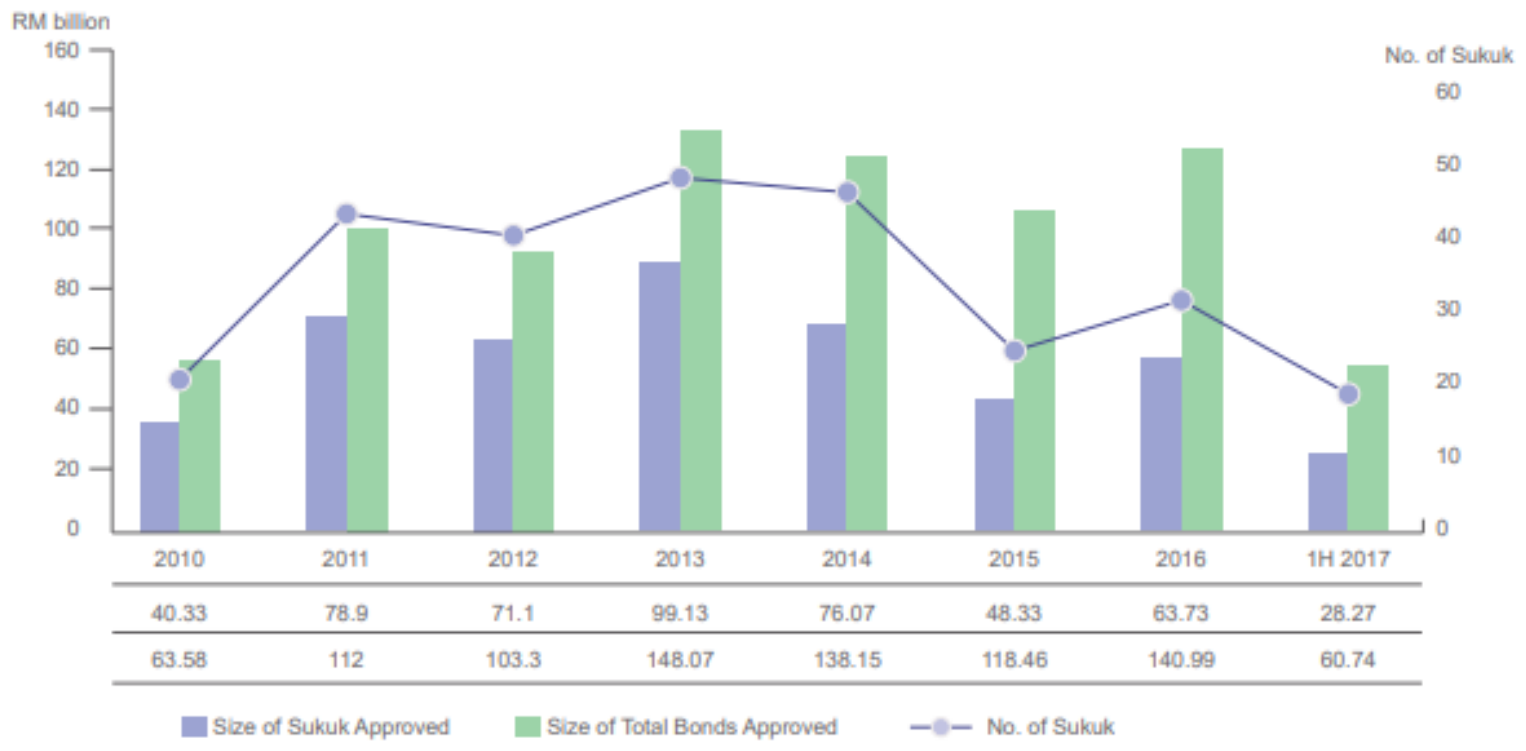

Malaysia is issuing Sukuk dominantly on the basis of Murabaha Sukuk structure. However, the government of Malaysia is encouraging Sukuk issuers to issue Sukuk based on Wakalah and Ijarah Sukuk structures by giving incentives in the form of tax deductions (Thomson Reuters, 2017). Malaysia's Sukuk issuance by sector including; financial service, infrastructure and utilities, diversified holdings, 
transportation, property and real estate, plantation and agriculture, asset-backed securities, mining and petroleum, industrial products, and consumer products is presented in Figure 13. Quasi government and corporate Sukuk issuances are dominated by financial services and infrastructure and utilities sectors.

Figure 13: Malaysia’s Sukuk Issuance by Sector

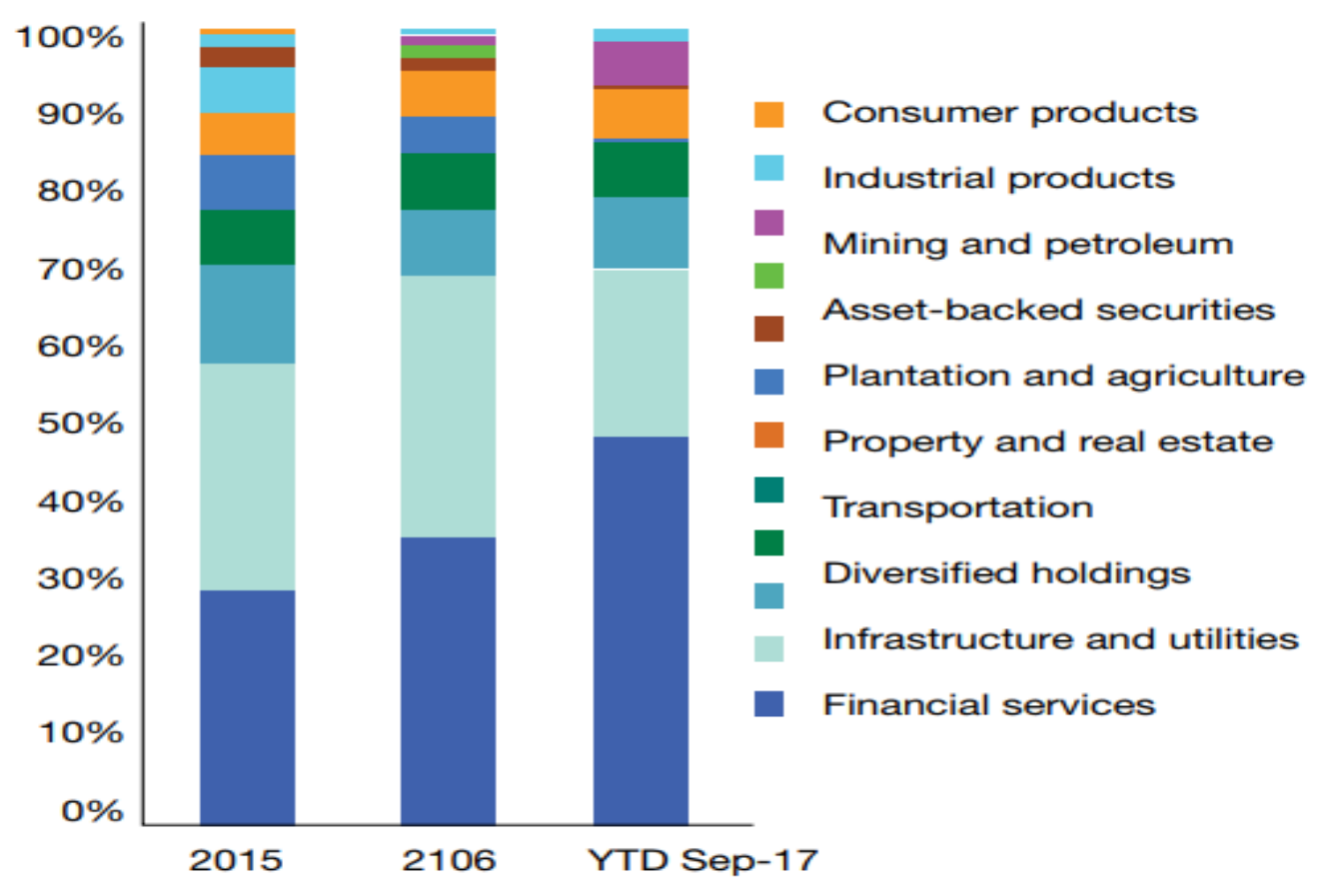

\section{Proposed Model for Pakistan}

In line with the international trend, the global Sukuk market in Pakistan was established in 2005 and its first international sovereign Sukuk was worth US\$ 600 million. In 2006, first domestic Sukuk was issued. Status wise Sukuk issuance in Pakistan is listed below (Table 1). The total number of issued Sukuk is 107 including privately placed and listed at the stock exchange.

Table 1: Status wise Sukuk Issuance in Pakistan

\section{Listing Status \\ Number of Issues \\ Amount in Billion Rs}

\begin{tabular}{|l|c|c|}
\hline Privately Placed & 99 & 1156.58 \\
\hline Listed & 8 & 47.70 \\
\hline Total & 107 & 1204.28 \\
\hline
\end{tabular}

Figure 14: Domestic Sukuk Structure 


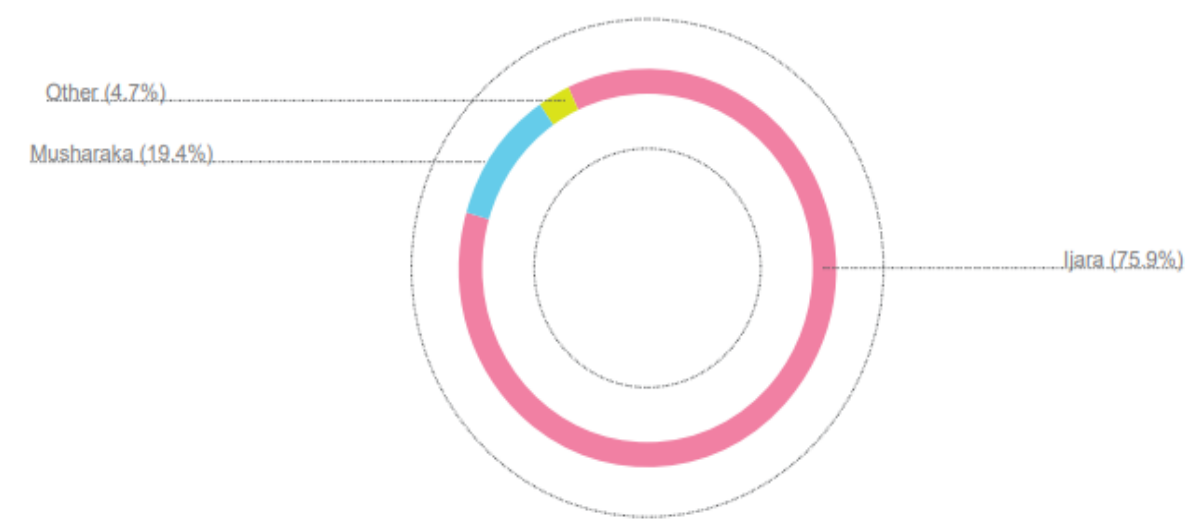

Domestic Sukuk structure is mainly based on Musharakah and Ijarah modes of Islamic finance. And the Sukuk al Ijarah has the dominant share in the domestic Sukuk market with 75.9 percent value since all sovereign Sukuk are based of Ijarah mode of Islamic Finance.

Figure 15: Historical trend in terms of Sukuk Value

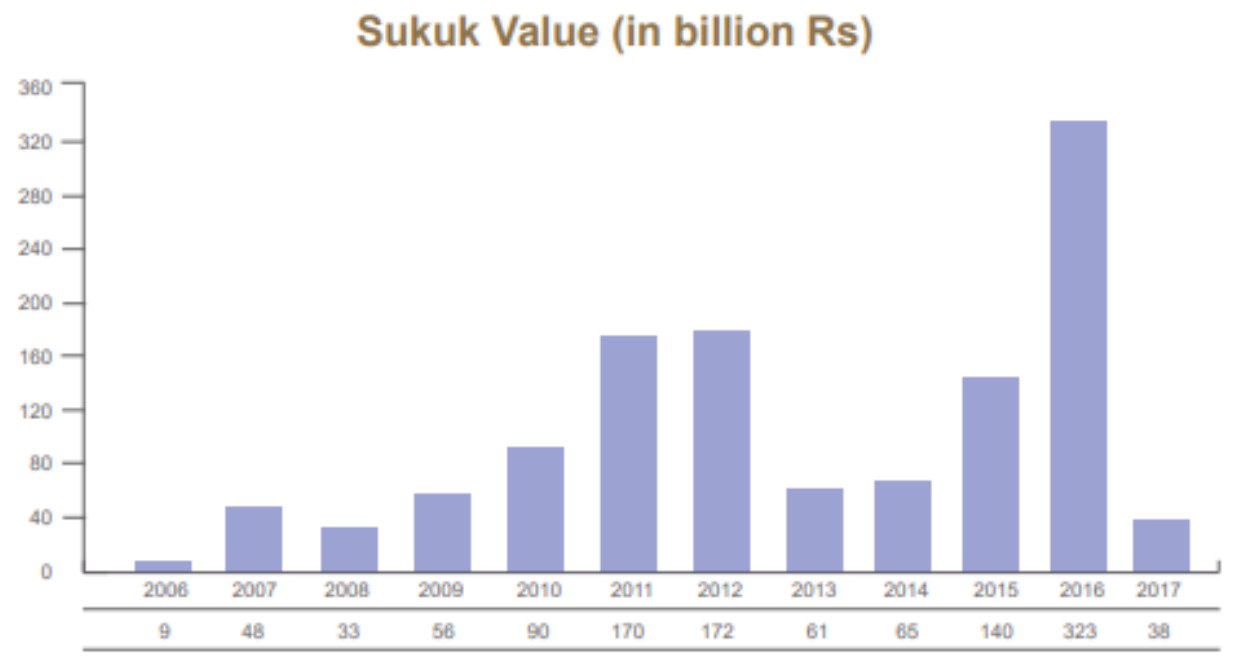

In spite of the fact that a late participant to the Sukuk maket, Pakistan has been encountering enduring development in Sukuk since 2007. The development backed off in 2008 in terms of Sukuk value however it began grabbing again particularly for the years 2010-12 and 2015-16. In 2017, 9 Sukuk were issued with Rs 38 billion Sukuk value.

Figure 16: Historical Trend in terms of number of Sukuk Issues 


\section{Number of Sukuk Issues}

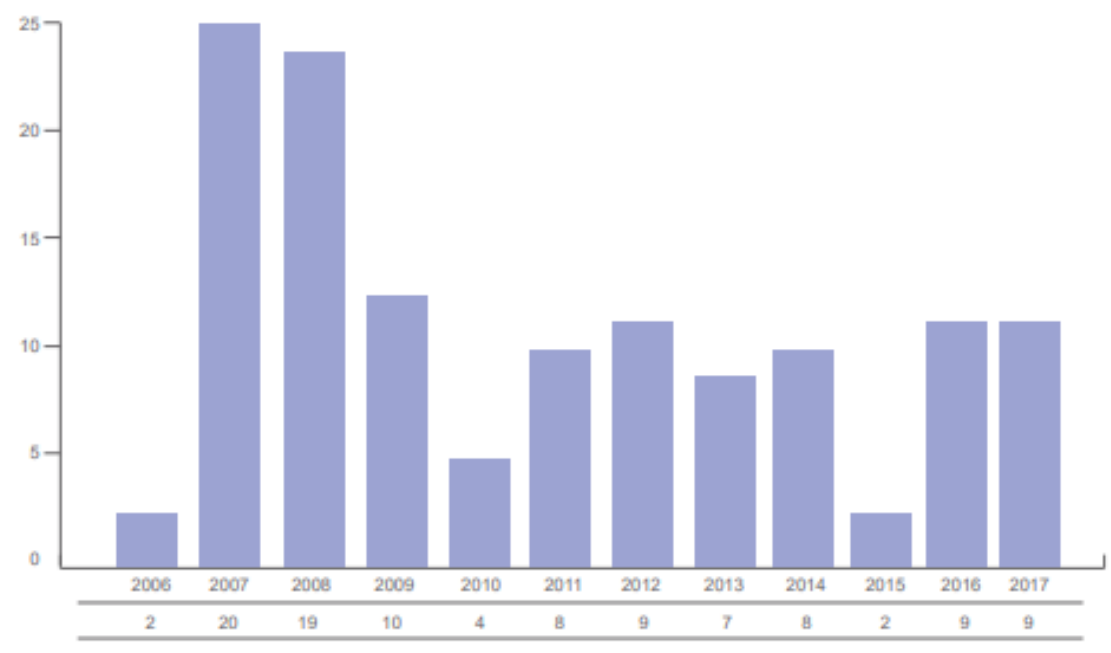

In Figure 16, there is limited number of Sukuk issuance after 2008. Though, there has been a substantial rise in terms of Sukuk value. This might be because of the fact that the majority of the Sukuk issuances during these years were Government of Pakistan Ijarah Sukuk that were having high Sukuk value. Government, quasi-government and the corporate sector are the major bond issuers in the Islamic bond industry of Pakistan

Table 2: Sukuk Issuances Corporate, Sovereign, and Quasi-Sovereign

\begin{tabular}{|c|c|c|c|}
\hline Year & Corporate & Sovereign & Quasi - Sovereign \\
\hline $\mathbf{2 0 0 6}$ & 7.2 & 0 & 92.8 \\
\hline $\mathbf{2 0 0 7}$ & 55.5 & 0 & 44.5 \\
\hline $\mathbf{2 0 0 8}$ & 48.6 & 14 & 37.4 \\
\hline $\mathbf{2 0 0 9}$ & 43.3 & 29 & 27.7 \\
\hline $\mathbf{2 0 1 0}$ & 27.1 & 55.7 & 17.2 \\
\hline $\mathbf{2 0 1 1}$ & 15.9 & 72.7 & 11.4 \\
\hline $\mathbf{2 0 1 2}$ & 11.5 & 79.3 & 9.2 \\
\hline $\mathbf{2 0 1 3}$ & 10.7 & 78.5 & 10.8 \\
\hline $\mathbf{2 0 1 4}$ & 11 & 78.3 & 10.7 \\
\hline $\mathbf{2 0 1 5}$ & 9.2 & 79.3 & 11.5 \\
\hline $\mathbf{2 0 1 6}$ & 8.9 & 74.2 & 16.9 \\
\hline $\mathbf{2 0 1 7}$ & 10.5 & 73.1 & 16.4 \\
\hline
\end{tabular}

Overall, the corporate Sukuk has the dominant share till 2009. After that an auxiliary move from corporate to sovereign Sukuk occurred and sovereign Sukuk maintained their dominant share with 73.1 percent in absolute estimation of Sukuk issued in Pakistan. The shares of quasi-sovereign Sukuk and corporate Sukuk are 16.4 percent and 10.5 percent respectively.

Pakistan is gradually understanding that the gradual shift towards Sukuk - rather than conventional bonds - is driven by both market forces demand and supply. Commercial banks, mutual funds, employees' funds and other financial institutions are the main investors of Sukuk. While Sukuk have been issued by corporate entities such as Byco Oil Pakistan, Ghani Gases and Fatima Fertilizer as well as Islamic banks of Pakistan like Dubai Islamic Bank and Al Baraka Bank for their financing needs. Moreover, the Government of Pakistan is devising to offer foreign currency Sukuk of US\$ 1 billion (Islamic Finance News, 2018). The truth of the matter is that the principle explanation behind Pakistan to keep issuing Sukuk is to ensure that their local market will benefit, and there is little motivation to trust this will 
happen except if steps are taken to make a prosperous local market for Islamic financial instruments in Pakistan.

The issue of liquidity will grow faster in Pakistan with the development of Islamic Finance Industry. So the need is to develop a short term Shariah-compliant tool to broaden the depth and liquidity of Islamic financial market. Pakistan can replicate the Sukuk model of Malaysia as it has potential, legal framework, demand, and disposition to make a vigorous and prosperous market for Sukuk.

Classic structure

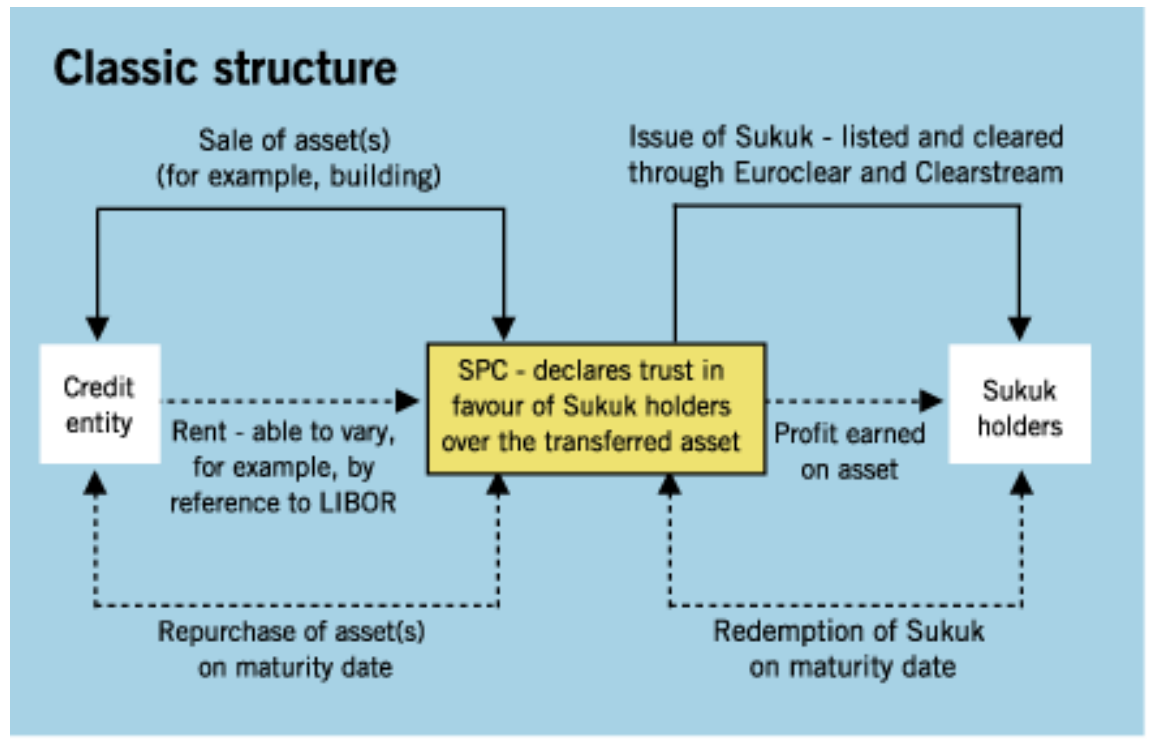

The introduction and development of investment funds that comply with Shariah principles in Pakistan is leading to a rising demand for Sukuk and other Shariah compliant instruments as new funding options. Recently, some well-known firms like Byco Oil Pakistan, Ghani Gases and Fatima Fertilizer issued Sukuk. To meet capital adequacy requirements, Dubai Islamic Bank and Al Baraka Bank issued Tier 2 Sukuk. The government of Pakistan is planning to issue foreign currency Sukuk in the international market at a value of US\$1 billion.(Ibrahim, 2017)

The proposed model of Pakistan is based on Sukuk al Istisna which is denoted as the "Islamic Project Bond". Istisna is an agreement of trade, whereby the financing party consents to convey a good or a property at a pre-decided future time at a decided cost. Sukuk al Istisna is derived from an agreement for a future delivery of constructed property. At the pre-determined time of delivery, the contractor/builder provides the property. Sukuk holders do not mean to hold the assets, they will be on-sold to a final purchaser, which could be the contractor. The Sukuk holder will get the proceeds of this sale. Usually the Sukuk al Istisna is joined with a forward lease contract to facilitate the Sukuk holder to get a return before the property distribution. The transaction structure of Sukuk al Istisna is illustrated in the following diagram:

Figure 17: Sukuk al Istisna transaction structure 


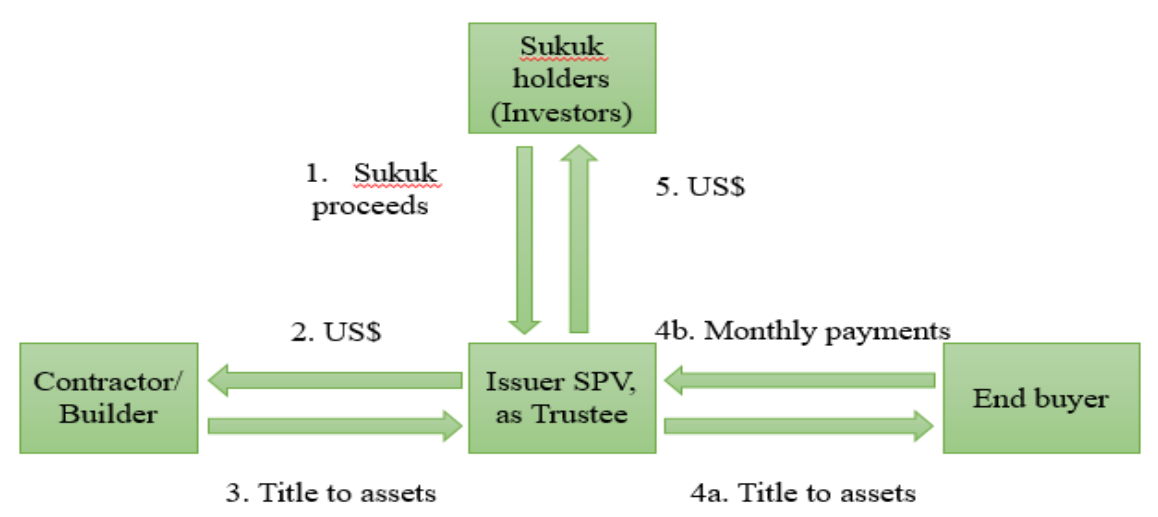

The transaction structure of Sukuk al Istisna consists of five steps. Initially, the issuer SPV supplies certificates of Sukuk to raise capital for the future manufactured or constructed property. Second step includes the payment to contractor/builder in order to build and deliver future manufactured or constructed property. In the next step, contractor/builder transferred the title to assets to the issuer SPV. Forth step consists of the sale or lease of the asset to the end buyer. And in return, the end buyer pays regular scheduled payments to the issuer SPV. Last but not least, the issuer SPV pays out the profit to the Sukuk holder.

Pakistan's Sukuk market is exposed to certain basic difficulties that need to be addressed before replicating the Malaysia Sukuk market. For instance, the presence of an active secondary trading market plays a pivotal role in the success of the Malaysian Sukuk market. So, Pakistan need to encourage the issuance of Sukuk with varied maturities, credit qualities, currencies and risk profiles. As a result, the investors would have different choices in the Sukuk market. For example, the current Sukuk system in Malaysia permits issuance of both ringgit and non-ringgit Sukuk.

Securities Exchange Commission of Pakistan (SECP) regulates the Sukuk market and all capital market instruments.

\section{Conclusion}

The absence of liquidity management has inflicted significant damage on the productivity of the Islamic financial institutions and has a major influence in expanding the likelihood of displaced commercial risk occurring (Aamir, 2017). Liquidity management capacity can be enhanced through the issuance of sovereign and corporate Sukuk for managing the capital needs in a Shariah compliant manner. Malaysia as a global center of Islamic finance can be the perfect example for Pakistan for the development of an effective and dynamic Sukuk market since Malaysia has the proper legal regulatory structure, demand and disposition. Sovereign and corporate Sukuk issuance would play an enormous role in helping the Pakistan's finances. Moreover, Sukuk issuance could aid broad-base development with in Pakistan due to recent development of green Sukuk. However, Pakistan should give support to retail participation by encouraging the issuance of Sukuk with varied maturities, credit qualities, currencies and risk profiles.

\section{References}

Abdul Majid, A. (2003). Development of Liquidity Management Instruments: Challenges and Opportunities. International Conference on Islamic Banking: Risk Management Regulation g and Supervision. Jakarta.

Ahmad, W., \& Radzi, R. M. (2011). Sustainability of Sukuk and Conventional Bond during Financial Crisis: Malaysia's Capital Market. Global Economy and Finance Journal, 33-45.

Awadzi, E. A. (2015). Designing Legal Frameworks for Public Debt Management. International Monetary Fund. 
Bank Negara Malaysia. (n.d.). List of Licensed Financial Institutions in Malaysia. Retrieved from Financial http://www.bnm.gov.my/index.php?ch=li\&cat=islamic\&type=IB\&fund=0\&cu=0

Stability:

International Islamic Financial Market. (2018). IIFM Sukuk Report. Kuala Lumpur.

Islamic Banking Department SBP. (2017). Islamic Banking Bulletin. State Bank of Pakistan.

Islamic Finance News. (2018). IFN Annual Guide. IFN.

Islamic Finance Sukuk Definition. (2015, February 27). Retrieved from Investment \& Finance: https://www.investment-and-finance.net/islamic-finance/tutorials/sukuk-definition.html

Islamic Financial Services Board. (2017). Islamic Financial Services Industry Stability Report. Kuala Lumpur: IFSB.

Mobin, M. A., \& Ahmad, A. F. (2014). Liquidity Management of Islamic Banks: The Evidence from Malaysian Practice. The Global Journal of Finance and Economics, 175-186.

Model of a Classic Sukuk Structure. (2009, August 25). Retrieved from Sukuk Islamic Financial: https://sukukindonesia.wordpress.com/2009/08/25/model-of-a-classic-sukuk-structure/

Mohamad, A., Mohamad, M., \& Samsudin, M. (2013). How Islamic Banks of Malaysia Managing Liquidity? An Emphasis on Confronting Economic Cycles. International Journal of Business and Social Science, 253-263.

Mohamad, S., \& Yusoff, M. F. (2008). Key Shari[ah Rulings on Sukuk Issuance in the Malaysian Islamic Capital Markets. In S. S. Ali, Islamic Capital Markets: Products, Regulations \& Development. Islamic Development Bank.

S \& P Global Ratings. (2017). Islamic Finance Outlook.

Saripudin, K. N., Mohamad, S., Razif, N. F., Abdullah, L. H., \& Abdul Rahman, N. N. (2012). Case Study on Sukuk Musharakah Issued in Malaysia . Middle-East Journal of Scientific Research, 168-175.

Shahar, W. S., Shahar, S. W., \& Jamlus, N. (2014). 1st International Conference on Management and Muamalah. 1st ICoMM, (pp. 139-150).

Thomson Reuters. (2017). Sukuk Perceptions \& Forecast Study: Poised for Growth.

Wikipedia. (2018, December 7). Sukuk Wikipedia. Retrieved from Sukuk: https://en.wikipedia.org/wiki/Sukuk

Yean, T. W. (2009). International Legal News. Retrieved from Sukuk: Issues and the Way Forward: www.iln.com/articles/pub_1674.pdf

\section{Appendix}

Figure 18: Global Islamic Finance Assets Distribution by Sector

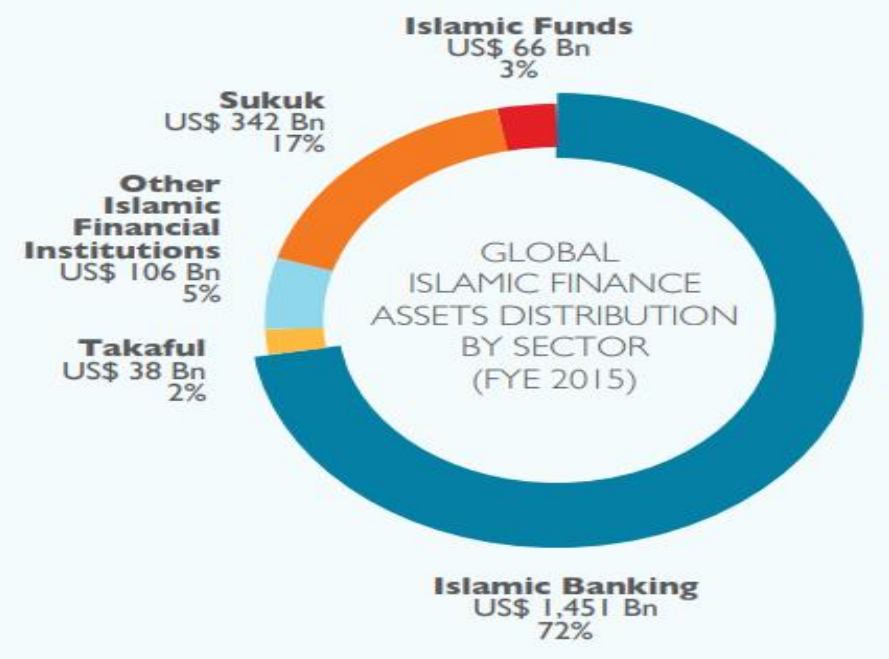



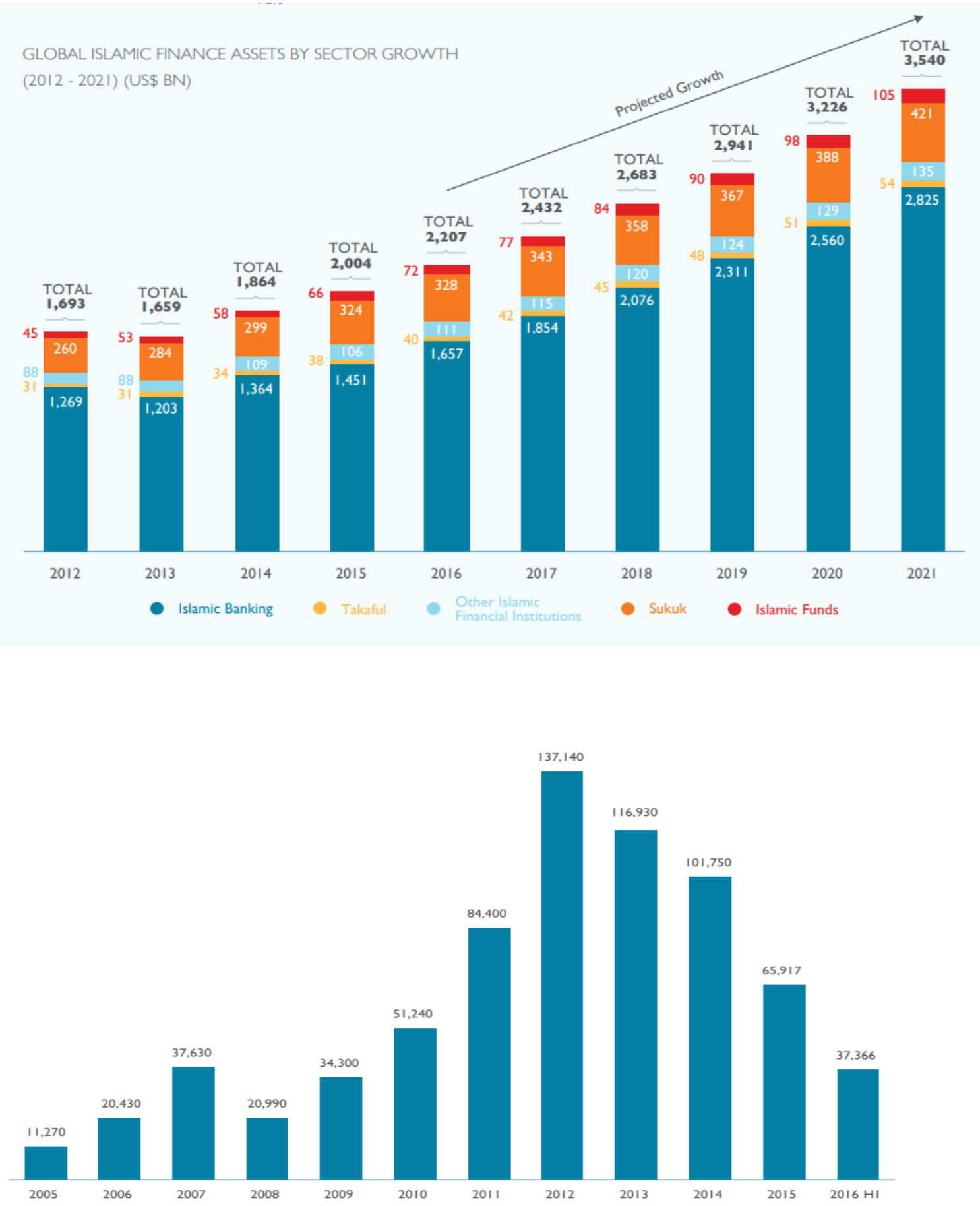

Figure 19: Global Aggregate Sukuk Historical Trend 


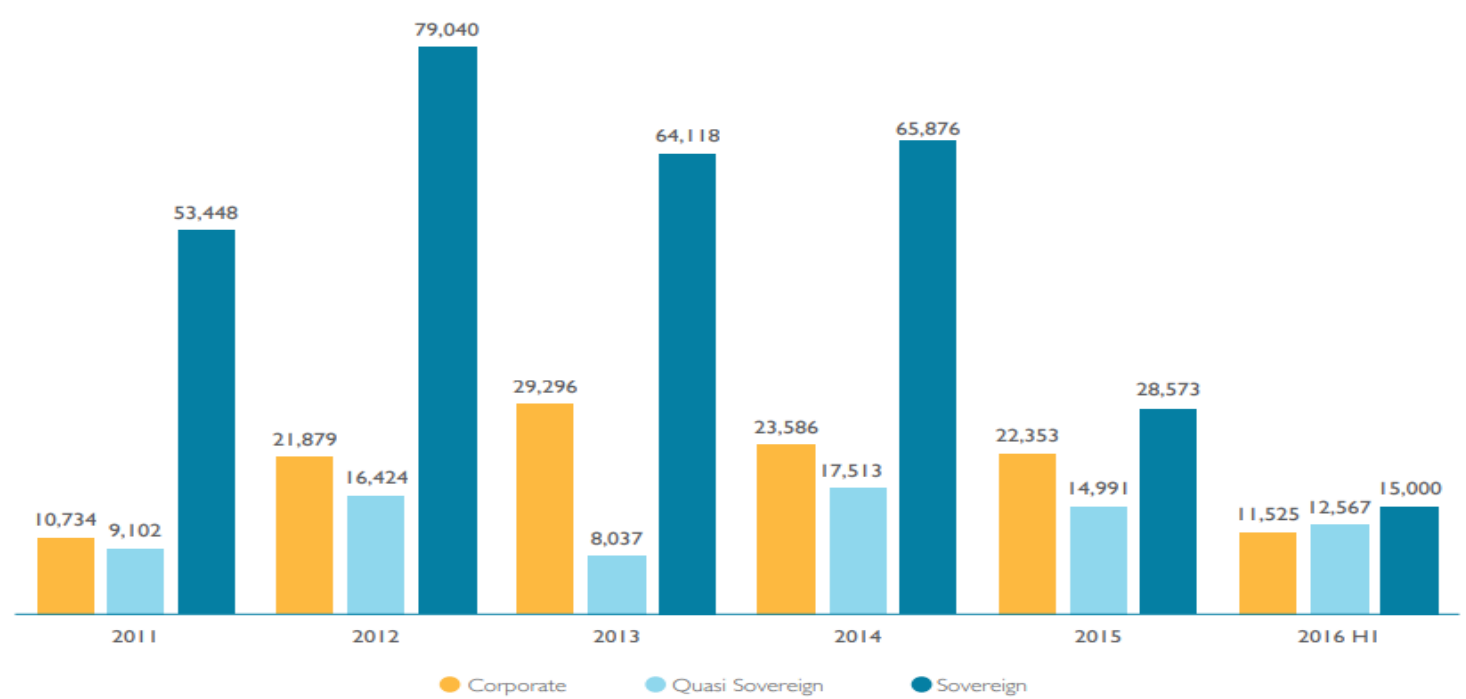

Figure 20: Global Sukuk Breakdown by Issuer Type

Figure 21: Global Sukuk Top Five Structures

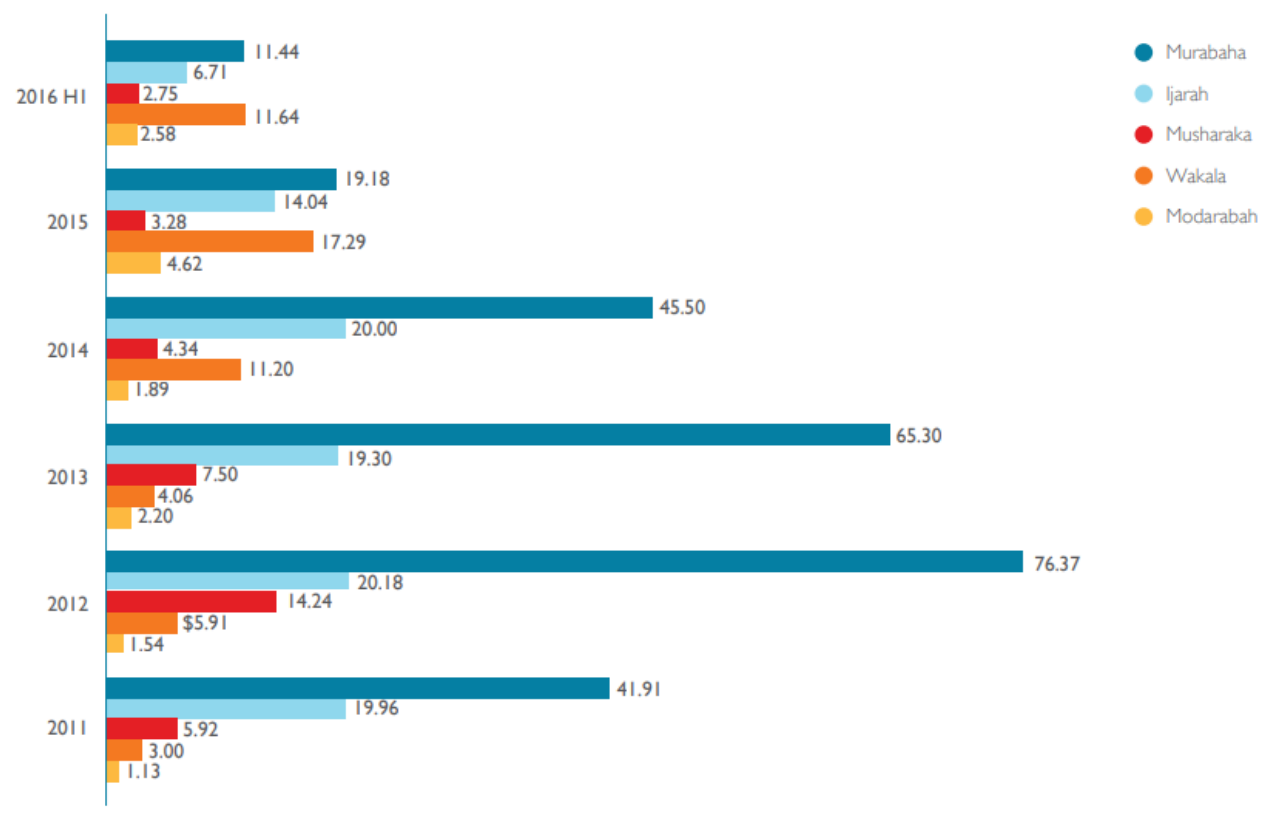

